\title{
Spatial Distribution of Fish Larvae in a Bay of the Gulf of California (June and November 1997) ${ }^{1}$
}

\author{
Martha Peguero-Icaza ${ }^{2,3}$ and Laura Sáncbez-Velasco ${ }^{2,4}$
}

\begin{abstract}
Bahía Concepción is one of the largest coastal bodies of water on the peninsular side of the Gulf of California, which is characterized by great fish species diversity. Spatial distributions of fish larvae in Bahía Concepción during June and November 1997 were analyzed; these months were representative of the extreme hydrographic conditions during an annual cycle in the Gulf. Zooplankton samples (333- $\mu \mathrm{m}$ conical net) and conductivity, temperature, and depth data were obtained at each sampling station. The Bray-Curtis dissimilarity index defined three groups of stations in June (mouth, central, and interior) and two in November (mouth and central-interior), which vary in species composition and dominance. In June, Gerreidae (Eucinostomus gracilis) and Clupeidae (Opistbonema sp.) larvae were the dominant species in the bay mouth; Sciaenidae type 1, Clupeidae (Harengula thrissina), and Pomacentridae (Stegastes rectifraenum) larvae were the dominant species in the central bay; and Gerreidae ( $E$. dowii) larvae in the bay interior. The differentiation of three groups is associated with variations in hydrographic conditions recorded from the mouth to the bay interior, coinciding with a well-defined thermocline throughout the bay as a result of weak winds prevailing in the central Gulf region. In November, Mullidae and Clupeidae (Etrumeus teres) larvae were the dominant taxa in the bay mouth, and Gobiidae (Ilypnus gilberti) and Blenniidae (Hypsoblennius gentilis) larvae dominated in the central and interior bay. The similarity of the larval composition of the central and interior bay is associated with a straight spatial gradient of temperature and salinity and homogeneity in the water column; this condition was caused by strong winds and tides that affect the region in late fall. In addition, the presence of mesopelagic species (e.g., Vinciguerria lucetia) in the bay interior during November indicates a clear influence of the Gulf waters in the bay at that time, possibly as a result of intensive mixing.
\end{abstract}

The Gulf of California (the Gulf) and its coastal bodies of water is a region of great ecological and fishery importance, charac-

\footnotetext{
${ }^{1}$ This study was supported by Instituto Politécnico Nacional (IPN) and CONACyT through project CGEPI 20010817 and CONACy T 34071-T. Manuscript accepted 20 October 2003.

${ }^{2}$ Centro Interdisciplinario de Ciencias Marinas, IPN, Ave. Instituto Politécnico Nacional s/n, Playa Palo de Santa Rita, La Paz, Baja California Sur, CP 23000, México.

${ }^{3}$ E-mail: tigermartha@yahoo.com.

${ }^{4}$ E-mail: lsvelasc@ipn.mx.
}

Pacific Science (2004), vol. 58, no. 4:567-578 (C) 2004 by University of Hawai'i Press All rights reserved terized by high species diversity and abundance of commercial species (Fisher et al. 1995, Cisneros-Mata et al. 1997). These biological characteristics are associated with complex oceanography and well-defined wind patterns that maintain high productivity in the region. Strong northwesterly winds and tides cause vertical mixing from late autumn until early spring, and weak southerly winds permit the thermocline formation in summer (Roden and Groves 1959, Badan-Dangon et al. 1985, Alvarez-Borrego and Lara-Lara 1991).

Bahía Concepción is one of the largest and shallowest coastal bodies of water on the peninsular side of the Gulf and is connected to the Gulf through a straight, permanent opening. Because of its permanent connec- 
tion, the bay may be an important nursery area for fish species that inhabit the region (Abitia et al. 1990, Rodríguez et al. 1992). Studies of fish larvae in the Gulf have increased since the 1970s (e.g., Moser et al. 1974, Green-Ruíz and Hinojosa-Corona 1997, Sánchez-Velasco et al. 2000, 2002), but little is known about the ichthyoplankton in Bahía Concepción and other bays of the Gulf. In Bahía Concepción the only ichthyoplankton data reported have been the presence of eggs and larvae of two sardine species in the bay mouth, coinciding with their spawning period in the Gulf (MuñetónGómez et al. 1994, Cota-Meza and MuñetónGómez 1995).

The objective of the study reported here was to determine the spatial distribution of fish larvae in Bahía Concepción during June and November 1997, two months that represent the extreme hydrographic conditions of an annual cycle in the Gulf of California.

\section{MATERIALS AND METHODS}

The sampling grid consisted of 36 stations located throughout the bay, which was sampled during the day on 21 and 22 June and 29 and 30 November 1997 (Figure 1). The temperature and conductivity of the water column at each station were measured with an Inter-Ocean CTD (Conductivity Temperature Depth Profiler). The zooplankton samples were obtained using a $150-\mathrm{cm}$-long conical net with a $60-\mathrm{cm}$ mouth diameter and $333-\mu \mathrm{m}$ mesh size. Surface collections were of $5 \mathrm{~min}$ duration at a ship speed of $4.5 \mathrm{~km}$ / hr along a semicircular course. The filtered water volume was calculated using calibrated flowmeters placed in the mouth of the net. Each sample was fixed with 5\% formaldehyde buffered with sodium borate (Kramer et al. 1972, Smith and Richardson 1979).

Zooplanktonic biomass was estimated by displacement volume and standardized to milliliters per $1,000 \mathrm{~m}^{3}$ of sea surface (Kramer et al. 1972). Fish larvae were removed from the samples after biomass determination and identified mainly according to the descriptions of Moser (1996) and JiménezRosenberg (1994, 1998). Larval abundance was standardized to the number of larvae per $100 \mathrm{~m}^{3}$ of sea surface (Kramer et al. 1972).

Similarities among sampling stations in each period were measured using taxa with a frequency of occurrence $\geq 5 \%$ (Bray and Curtis 1957, Field et al. 1982). To reduce the influence of the most abundant species, the standardized data were root-root transformed. Groups of stations were defined using the Bray-Curtis dissimilarity index, a technique that is sufficiently robust for many marine data because it is not affected by multiple absences and gives more weight to abundant species than to rare ones (Bray and Curtis 1957, Field et al. 1982). Dendrograms were constructed using the UPGMA method (So$\mathrm{kal}$ and Sneath 1963). The Olmstead-Tukey test, which incorporates the frequency and abundance of species, was used to determine the dominant species of each station group (Sokal and Rohlf 1979, Sánchez-Velasco et al. 1996).

\section{RESULTS}

\section{Hydrograpby and Zooplanktonic Biomass}

The mean sea-surface temperature was significantly higher in June $\left(29^{\circ} \mathrm{C}\right)$ than in November $\left(24^{\circ} \mathrm{C}\right)$, and the mean zooplankton biomass was significantly higher in November $\left(458 \mathrm{ml} / 1,000 \mathrm{~m}^{3}\right)$ than in June $(196 \mathrm{ml} /$ $\left.1,000 \mathrm{~m}^{3}\right)(P<0.05)$. The mean sea-surface salinity was similar during both periods $(35.5$ psu).

The spatial distribution of hydrographic variables showed higher spatial gradients in June than in November. The lowest seasurface temperature and sea-surface salinity values were recorded in the mouth zone in June, whereas the highest sea-surface temperature and lowest sea-surface salinity values were recorded in this zone in November. The highest zooplankton biomass values were in the vicinity of the mouth and in the central bay during both periods (Figure 2).

The vertical distribution of temperature showed a marked thermocline between 10and $17-\mathrm{m}$ depth from the mouth zone to the interior bay in June, and at $28 \mathrm{~m}$ in the mouth zone in November. Temperature did not vary with depth in the central or interior portions 


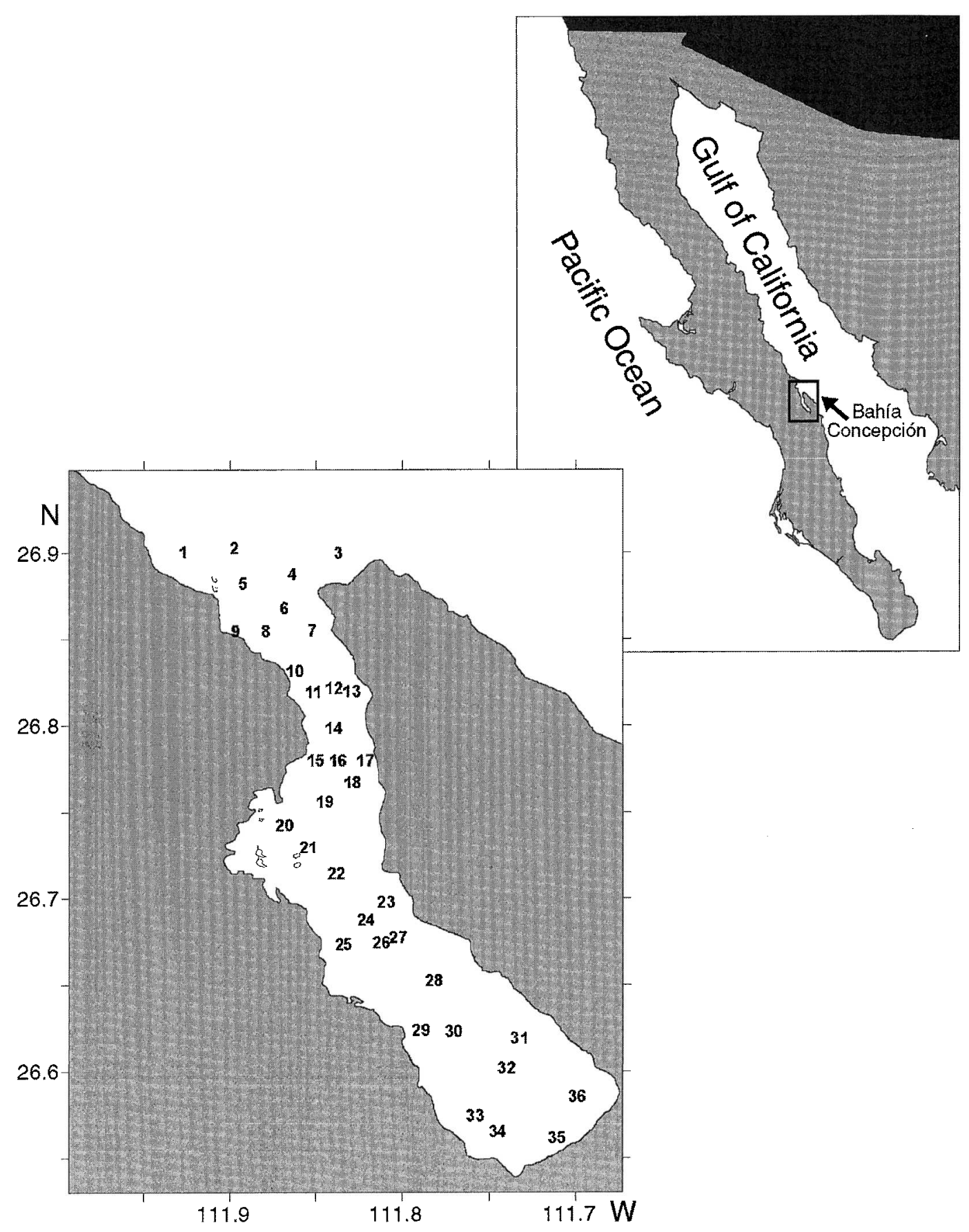

FIGURE 1. Location of study area and sampling stations. 

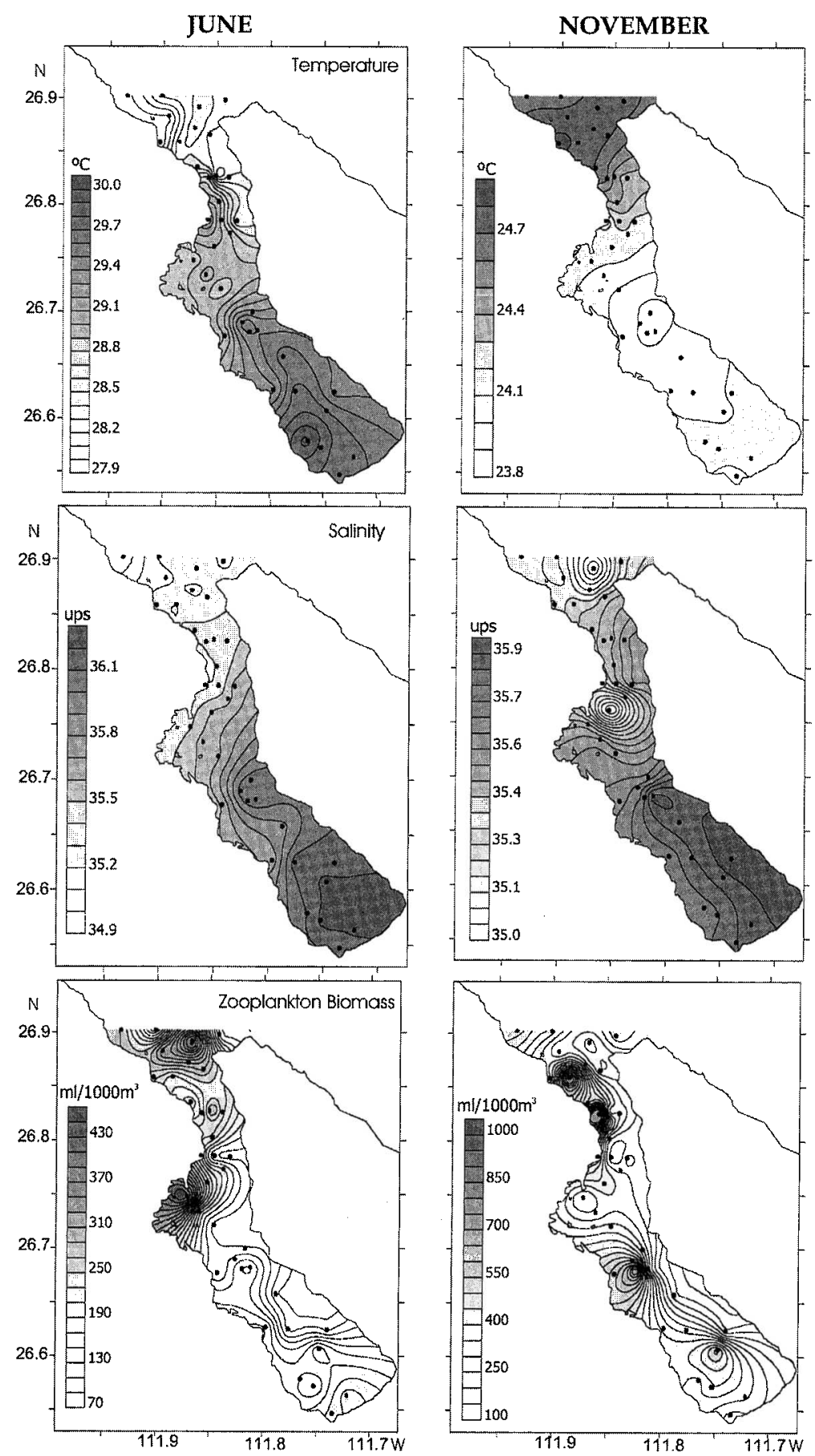

Figure 2. Spatial distribution of sea-surface temperature, salinity, and zooplankton biomass in Bahía Concepción (Gulf of California) during June and November 1997. 

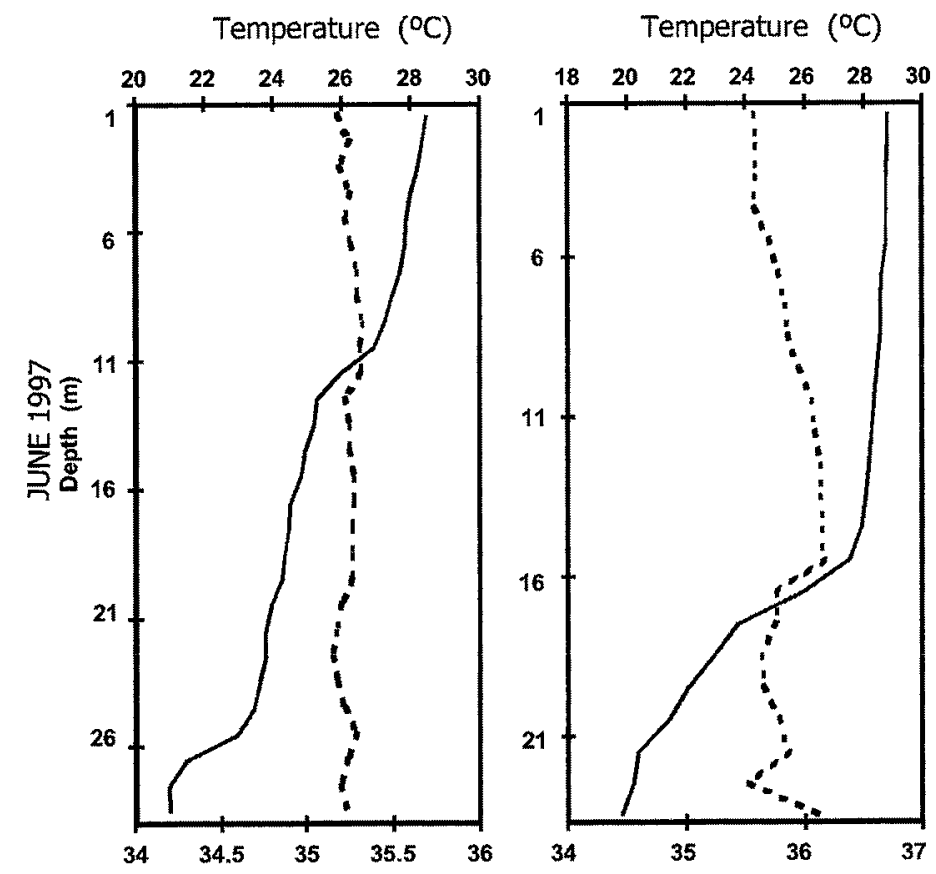

Temperature $\left({ }^{\circ} \mathrm{C}\right)$
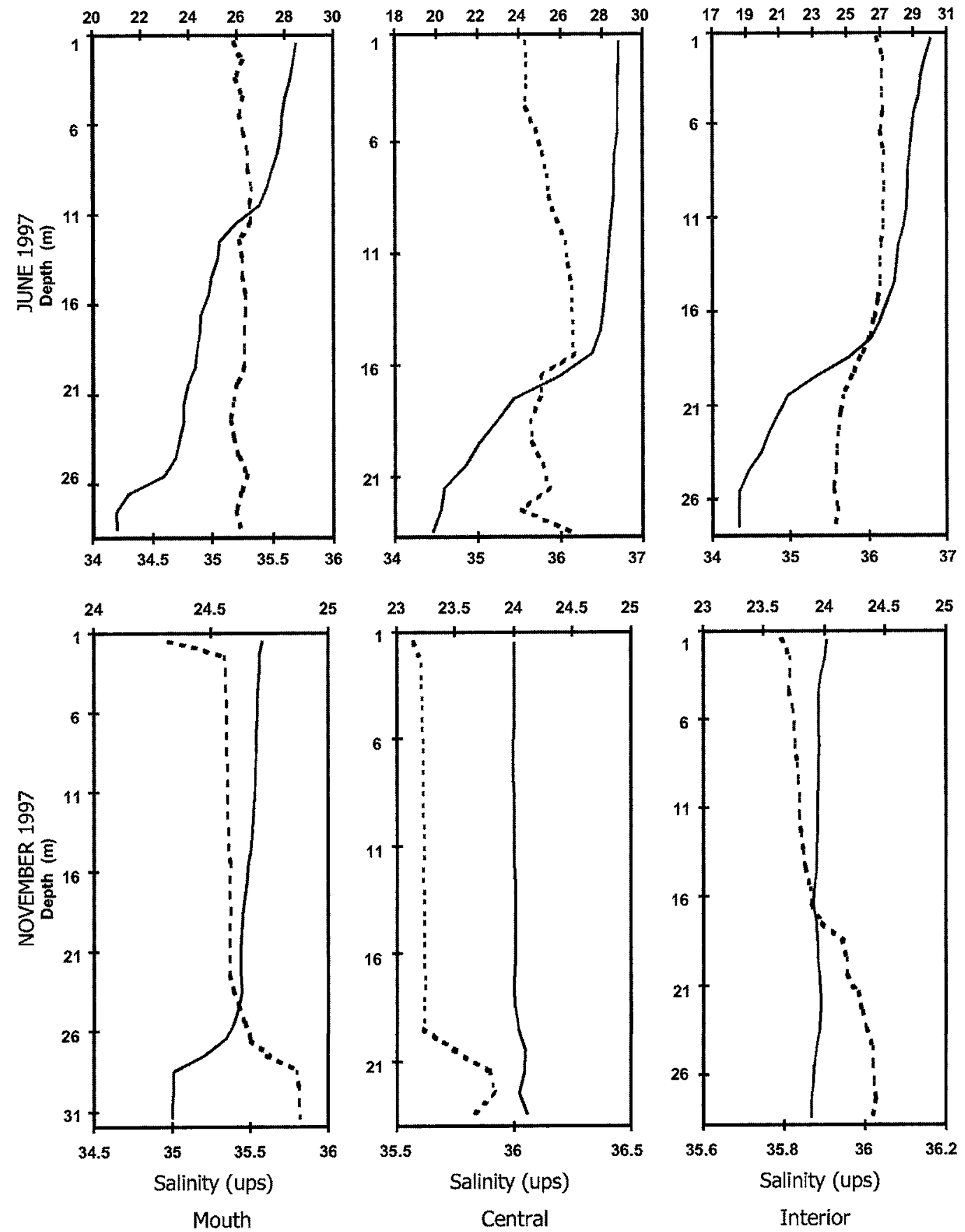

Figure 3. Vertical profiles of temperature (solid line) and salinity (dashed line) in the mouth, central, and interior of Bahía Concepción (Gulf of California) during June and November 1997. 
TABLE 1

Mean Abundance (Number of Larvae per $100 \mathrm{~m}^{3}$ ) and Frequency of Occurrence (\%) of Fish Larval Taxa Identified in Bahía Concepción (Gulf of California) during Cruises in June and November 1997

\begin{tabular}{|c|c|c|c|c|c|}
\hline \multirow[b]{2}{*}{ Taxon } & \multirow{2}{*}{$\begin{array}{c}\text { Adult } \\
\text { Habitat } \\
\text { Type }\end{array}$} & \multicolumn{2}{|c|}{ June } & \multicolumn{2}{|c|}{ November } \\
\hline & & $\begin{array}{c}\text { Mean } \\
\text { Abundance }\end{array}$ & $\begin{array}{l}\text { Frequency of } \\
\text { Occurrence (\%) }\end{array}$ & $\begin{array}{c}\text { Mean } \\
\text { Abundance }\end{array}$ & $\begin{array}{c}\text { Frequency of } \\
\text { Occurrence }(\%)\end{array}$ \\
\hline Sciaenidae type 1 & sd & 5.60 & 62 & 0.20 & 11 \\
\hline Opisthonema sp. & $\mathrm{cp}$ & 7.90 & 53 & 0.40 & 17 \\
\hline Eucinostomus gracilis & sd & 31.40 & 47 & 0.50 & 25 \\
\hline Eucinostomus dowii & sd & 5.30 & 47 & 0.20 & 11 \\
\hline Harengula thrissina & $\mathrm{cp}$ & 2.40 & 38 & 0.20 & 6 \\
\hline Paraclinus sp. 1 & sd & 1.40 & 29 & 0.20 & 17 \\
\hline Stegastes rectifraenum & sd & 1.80 & 29 & & \\
\hline Xenistius califormiensis & sd & 0.90 & 24 & 0.10 & 8 \\
\hline Eucinostomus sp. & sd & 3.90 & 24 & & \\
\hline Haemulidae type 1 & sd & 0.50 & 18 & & \\
\hline Caranx caballus & $\mathrm{cp}$ & 0.50 & 15 & & \\
\hline Mullidae type 1 & sd & 0.70 & 12 & 12.60 & 92 \\
\hline Clinidae type 1 & sd & 0.30 & 12 & & \\
\hline Hyporbampbus rosae & $c p$ & 0.20 & 12 & & \\
\hline Scomberomorus sierra & $\mathrm{cp}$ & 0.50 & 12 & & \\
\hline Diapterus peruvianus & sd & 2.30 & 9 & 0.30 & 8 \\
\hline Haemulidae type 2 & sd & 0.40 & 9 & 0.10 & 3 \\
\hline Kyphosidae type 1 & sd & 0.10 & 9 & & \\
\hline Sphoeroides type 1 & sd & 0.20 & 9 & & \\
\hline Sciaenidae type 2 & sd & 0.20 & 6 & 4.10 & 6 \\
\hline Gillellus semicinctus & sd & 0.10 & 6 & 0.01 & 3 \\
\hline Scomberomorus sp. & $\mathrm{cp}$ & 0.20 & 6 & 0.10 & 3 \\
\hline Abudefduf troscbelii & sd & 0.10 & 6 & & \\
\hline Exocoetidae type 1 & $\mathrm{cp}$ & 0.10 & 6 & & \\
\hline Orthopristis reddingi & sd & 0.50 & 6 & & \\
\hline Serranus sp. & sd & 0.01 & 3 & 1.40 & 36 \\
\hline Hypsoblennius gentilis & sd & 0.01 & 3 & 3.20 & 28 \\
\hline Paralabrax maculatofasciatus & sd & 0.01 & 3 & 0.60 & 20 \\
\hline Gobiidae type 1 & sd & 0.01 & 3 & 0.20 & 8 \\
\hline Oligoplites saurus inornatus & $c p$ & 0.10 & 3 & 0.10 & 6 \\
\hline Stereolepis gigas & sd & 0.01 & 3 & 0.10 & 3 \\
\hline Caranx sexfasciatzes & $\mathrm{cp}$ & 0.30 & 3 & & \\
\hline Chaetodon bumeralis & sd & 0.01 & 3 & & \\
\hline Cblorosconbus orqueta & $\mathrm{cp}$ & 0.20 & 3 & & \\
\hline Dactyloscopidae type 1 & sd & 0.10 & 3 & & \\
\hline Dactyloscopidae type 2 & sd & 0.00 & 3 & & \\
\hline Dactyloscopidae type 3 & sd & 0.01 & 3 & & \\
\hline Decapterus sp. & $\mathrm{cp}$ & 0.01 & 3 & & \\
\hline Eucinostomus currani & sd & 0.20 & 3 & & \\
\hline Fodiador acutus rostratus & $\mathrm{cp}$ & 0.01 & 3 & & \\
\hline Gobiidae type 4 & sd & 0.01 & 3 & & \\
\hline Hemirrampbus saltator & $\mathrm{cp}$ & 0.01 & 3 & & \\
\hline Hypsoblennius brevipinnis & sd & 0.01 & 3 & & \\
\hline Lytbrypnus dalli & sd & 0.01 & 3 & & \\
\hline Serranidae type 1 & sd & 0.01 & 3 & & \\
\hline Sparidae type 1 & sd & 0.01 & 3 & & \\
\hline Gobiidae type 3 & sd & 0.10 & 3 & & \\
\hline Ilypnus gilberti & sd & & & 11.40 & 61 \\
\hline Pomacentridae type 1 & sd & & & 3.60 & 61 \\
\hline Calamus bracbysomus & sd & & & 1.60 & 28 \\
\hline Labrisomus xanti & sd & & & 1.40 & 25 \\
\hline Bentbosema sp. & $\mathrm{mp}$ & & & 0.80 & 22 \\
\hline Vinciguerria lucetia & $\mathrm{cp}$ & & & 0.40 & 17 \\
\hline
\end{tabular}


TABLE 1 (continued)

\begin{tabular}{|c|c|c|c|c|c|}
\hline \multirow[b]{2}{*}{ Taxon } & \multirow{2}{*}{$\begin{array}{l}\text { Adult } \\
\text { Habitat } \\
\text { Type }^{a}\end{array}$} & \multicolumn{2}{|c|}{ June } & \multicolumn{2}{|c|}{ November } \\
\hline & & $\begin{array}{c}\text { Mean } \\
\text { Abundance }\end{array}$ & $\begin{array}{l}\text { Frequency of } \\
\text { Occurrence (\%) }\end{array}$ & $\begin{array}{c}\text { Mean } \\
\text { Abundance }\end{array}$ & $\begin{array}{l}\text { Frequency of } \\
\text { Occurrence (\%) }\end{array}$ \\
\hline Etrumneus teres & $\mathrm{cp}$ & & & 3.30 & 14 \\
\hline Engraulis mordax & $\mathrm{cp}$ & & & 0.50 & 11 \\
\hline Pontinus sp. & sd & & & 0.10 & 11 \\
\hline Etropus crossotus & sd & & & 0.50 & 8 \\
\hline Mugil sp. & sd & & & 0.10 & 8 \\
\hline Prionotus sp. & sd & & & 0.10 & 8 \\
\hline Sardinops caeruleus & $\mathrm{cp}$ & & & 0.10 & 8 \\
\hline Sciaenidae type 4 & sd & & & 0.10 & 8 \\
\hline Anisotremus davidsonii & sd & & & 0.10 & 6 \\
\hline Apogon atricaudus & sd & & & 0.10 & 6 \\
\hline Bothidae type 1 & $s d$ & & & 0.10 & 6 \\
\hline Caranx sp. & $\mathrm{cp}$ & & & 0.20 & 6 \\
\hline Coryphopterus nicholsii & sd & & & 0.10 & 6 \\
\hline Labrisomidae type 1 & sd & & & 0.10 & 6 \\
\hline Merluccius productus & $\mathrm{dd}$ & & & 0.10 & 6 \\
\hline Mugil curema & sd & & & 0.20 & 6 \\
\hline Paralichthydae type 1 & sd & & & 0.30 & 6 \\
\hline Scomber japonicus & $\mathrm{cp}$ & & & 0.10 & 6 \\
\hline Spboeroides type 2 & sd & & & 0.10 & 6 \\
\hline Atherinidae type 1 & $\mathrm{cp}$ & & & 0.01 & 3 \\
\hline Dactyloscopidae type 4 & sd & & & 0.01 & 3 \\
\hline Dactyloscopidae type 5 & sd & & & 0.10 & 3 \\
\hline Fistularia conmersoni & sd & & & 0.01 & 3 \\
\hline Gobiidae type 2 & sd & & & 0.01 & 3 \\
\hline Gonostomatidae type 1 & $\mathrm{mp}$ & & & 0.01 & 3 \\
\hline Howellidae sp. & $m p$ & & & 0.01 & 3 \\
\hline Labrisomidae type 2 & sd & & & 0.01 & 3 \\
\hline Labrisomidae type 3 & sd & & & 0.01 & 3 \\
\hline Lythrypnus sp. & sd & & & 0.10 & 3 \\
\hline Phosichthydae type 1 & $m p$ & & & 0.10 & 3 \\
\hline Sciaenidae type 3 & sd & & & 0.20 & 3 \\
\hline Selene peruviana & $\mathrm{cp}$ & & & 0.10 & 3 \\
\hline Spboeroides type 3 & sd & & & 0.01 & 3 \\
\hline Symphurus type 1 & sd & & & 0.01 & 3 \\
\hline Symphurus type 2 & sd & & & 0.10 & 3 \\
\hline Syngnatbus californiensis & sd & & & 0.01 & 3 \\
\hline Synodus type 1 & sd & & & 0.10 & 3 \\
\hline Synodus type 2 & sd & & & 0.01 & 3 \\
\hline Number of species & & 47 & & 63 & \\
\hline
\end{tabular}

${ }^{a}$ sd, shallow demersal; dd, deep demersal; cp, coastal pelagic; mp, mesopelagic.

of the bay in November. A weak halocline was found at $16 \mathrm{~m}$ in the central and interior bay in June, and between 28 and $25 \mathrm{~m}$ in the mouth and central zone in November (Figure 3).

\section{Fisb Larvae}

A total of 2,327 larvae was collected in June, with 21 families and 47 lower taxa identified, and a total of 1,118 larvae was collected in November, which included 33 families and 63 lower taxa. Larvae of shallow demersal species constituted more than $73 \%$ of the total larvae caught during both periods, with 10\% mesopelagic and deep demersal species in November (Table 1). The most abundant families were Gerreidae (62\%) and Clupeidae $(15 \%)$, accounting for $75 \%$ of the total larvae caught in June. Mullidae (27\%), Gobiidae 

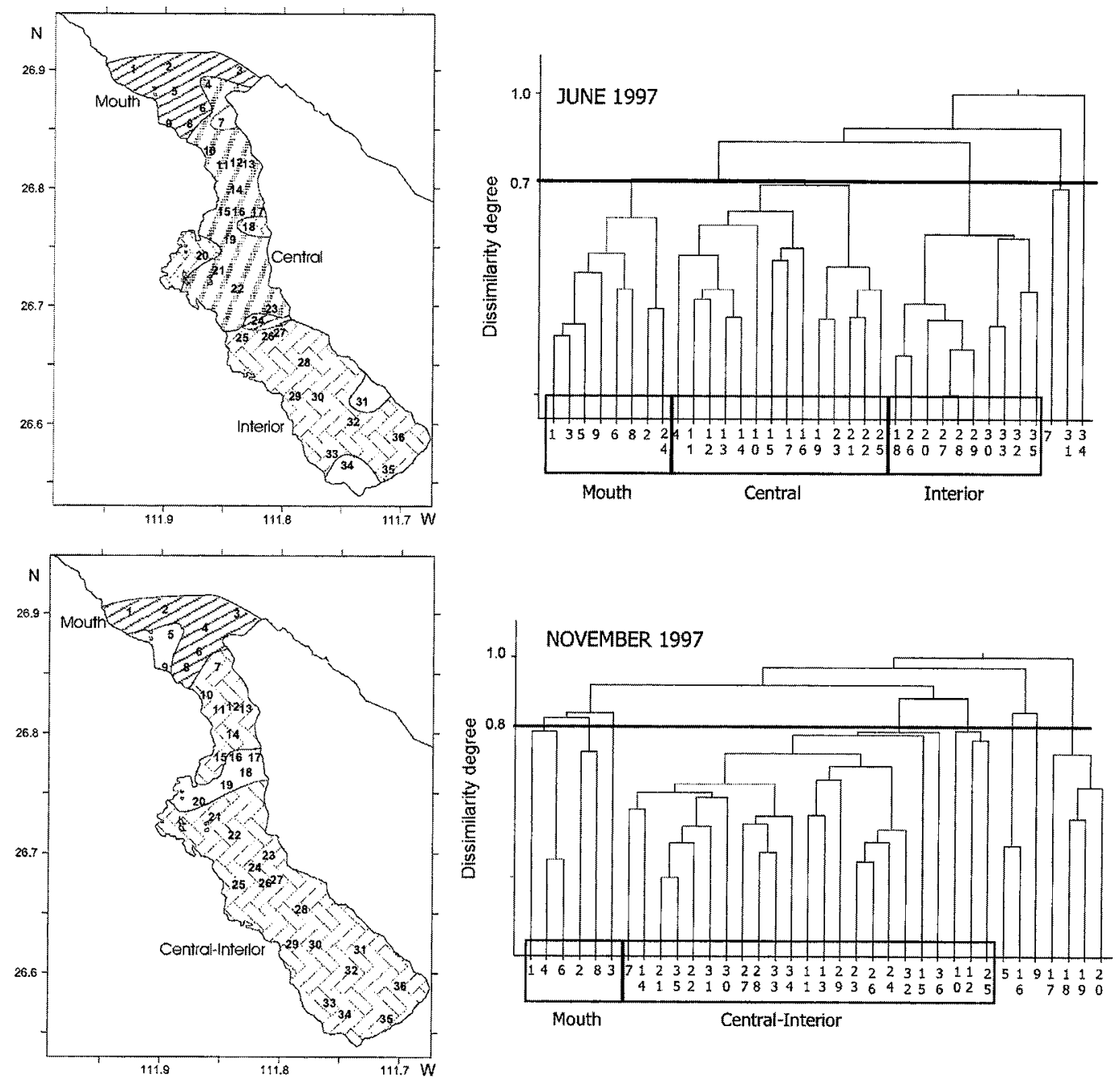

FIGURE 4. Dendrograms of sampling station groups defined by the Bray-Curtis dissimilarity index and UPGMA agglomerative method, and their location in Bahía Concepción (Gulf of California) during June and November 1997.

(20\%), and Clupeidae (9\%) were the most abundant families in November, accounting for $56 \%$ of the total larvae collected.

The Bray-Curtis dissimilarity index defined three groups of sampling stations in June at the 0.7 dissimilarity level (Figure 4 ). The first group of stations $(n=8)$ was located at the mouth zone, and the ichthyoplankton collections were dominated by Eucinostomus gracilis and Opistbonema sp. Fourteen stations from the central portion of the bay were grouped, characterized by having a higher larval abundance and number of species than at the mouth and interior zones of the bay. Sciaenidae type 1, Opistbonema sp., Stegastes rectifraenum, E. gracilis, and Harengula thrissina were the dominant species in the central zone. Ten stations from the interior portion of the bay were grouped, with the lowest larval abundance and species number. Sciaenidae type 1 and $E$. dowii were the dominant taxa in this zone (Table 2). 
TABLE 2

Dominant Fish Larval Taxa of the Sampling Station Groups in Bahía Concepción (Gulf of California) during June 1997 Determined by the Olmstead-Tukey Test

\begin{tabular}{|c|c|c|c|c|c|c|}
\hline \multirow[b]{2}{*}{ Dominant Taxon } & \multicolumn{2}{|c|}{ Mouth ${ }^{a}$} & \multicolumn{2}{|c|}{ Central $^{b}$} & \multicolumn{2}{|c|}{ Interior $^{c}$} \\
\hline & $\begin{array}{c}\text { Mean } \\
\text { Abundance }\end{array}$ & $\begin{array}{c}\text { Frequency of } \\
\text { Occurrence (\%) }\end{array}$ & $\begin{array}{c}\text { Mean } \\
\text { Abundance }\end{array}$ & $\begin{array}{c}\text { Frequency of } \\
\text { Occurrence }(\%)\end{array}$ & $\begin{array}{c}\text { Mean } \\
\text { Abundance }\end{array}$ & $\begin{array}{c}\text { Frequency of } \\
\text { Occurrence (\%) }\end{array}$ \\
\hline Eucinostomus gracilis & 20 & 100 & 10 & 57 & & \\
\hline Opistbonema sp. & 20 & 63 & 10 & 71 & & \\
\hline Sciaenidae type 1 & & & 70 & 93 & 2 & 60 \\
\hline Stegastes rectifraenum & & & 10 & 71 & & \\
\hline Harengula thrissina & & & 10 & 57 & & \\
\hline Eucinostomus dowii & & & & & 1 & 100 \\
\hline
\end{tabular}

" Number of taxa, 8 ; number of stations, 8 .

${ }^{b}$ Number of taxa, 24; number of stations, 14.

${ }^{c}$ Number of taxa, 7 ; number of stations, 10 .

Two groups of sampling stations were defined at the 0.8 dissimilarity level in November (Figure 4). The first group of stations $(n=6)$ was located at the mouth of the bay, and collections there were characterized by having low larval abundance and species number. Mullidae type 1 and Etrumeus teres were the dominant species. The second group of stations $(n=23)$ extended through the central and interior zones of the bay, with high larval abundance and species number. Mullidae type 1, Ilypnus gilberti, Sciaenidae type 2, Pomacentridae type 1, and Hypsoblennius gentilis were the dominant taxa (Table 3). Mesopelagic species, including Vinciguerria lucetia and Bentbosema sp., were found in collections from the central and interior of the bay.

\section{DISCUSSION}

Variation in the spatial and temporal distribution of fish larvae found in Bahía Concepción is affected by the wind patterns and hydrographic variation of the Gulf of California region. The water column stratification, with a well-defined thermocline in June and the hydrographic homogeneity of the water column in November, which is associated with the highest zooplanktonic biomass volumes and lowest sea-surface temperature

\section{TABLE 3}

Dominant Fish Larval Taxa of the Sampling Station Groups in Bahía Concepción (Gulf of California) during November 1997 Determined by the Olmstead-Tukey Test

\begin{tabular}{|c|c|c|c|c|}
\hline \multirow[b]{2}{*}{ Dominant Taxon } & \multicolumn{2}{|c|}{ Mouth $^{a}$} & \multicolumn{2}{|c|}{ Central-Interior } \\
\hline & $\begin{array}{c}\text { Mean } \\
\text { Abundance }\end{array}$ & $\begin{array}{c}\text { Frequency of } \\
\text { Occurrence (\%) }\end{array}$ & $\begin{array}{c}\text { Mean } \\
\text { Abundance }\end{array}$ & $\begin{array}{c}\text { Frequency of } \\
\text { Occurrence }(\%)\end{array}$ \\
\hline Mullidae type 1 & 20 & 100 & 10 & 100 \\
\hline Etrumeus teres & 20 & 83 & & \\
\hline Ilypnus gilberti & & & 20 & 83 \\
\hline Sciaenidae type 2 & & & 10 & 74 \\
\hline Pomacentridae type 1 & & & 10 & 78 \\
\hline Hypsoblennius gentilis & & & 5 & 44 \\
\hline
\end{tabular}

Number of taxa, 18; number of stations, 6 .

${ }^{b}$ Number of taxa, 33; number of stations, 23. 
of the study, is consistent with previous studies in the Gulf (e.g., Roden and Groves 1959, Badan-Dangon et al. 1985, Lavín et al. 1997). Strong northwesterly winds cause upwelling along the eastern shore and strong vertical mixing in the central Gulf from late autumn to early spring. During summer, weak southeasterly winds generate local upwelling along the western shore, influencing the water column stratification and a well-marked thermocline. These conditions are reflected in Bahía Concepción.

During the stratification period, strong differences in species composition and dominance are associated with variations in temperature, salinity, and zooplankton biomass in the mouth, central, and interior regions of the bay. Stations at the bay mouth were characterized by having lower temperatures and salinities and higher zooplankton biomass than those in the central and interior zones. The interior zone had the highest temperature and salinity. Partitioning the bay into three zones is consistent with findings of Obeso-Nieblas et al. (1996), who divided the bay into mouth, central, and interior zones according to current speed. Because of the geomorphology of the bay the highest speeds occurred in the bay mouth and the lowest occurred in its interior. Larvae of the coastal pelagic Opistbonema sp. and shallow demersal Eucinostomus gracilis were numerically dominant in the collections taken in the bay mouth during summer, coinciding with their spawning period in the central Gulf (Moser et al. 1974, Avalos-García et al. 2003). During summer, larvae of shallow demersal species such as Stegastes rectifraenum and Harengula thrissina dominated the plankton collections from the central bay, and $E$. dowii dominated in the bay interior. These latter three species also spawn in the central Gulf during summer, but with lower abundance than Opistbonema sp. and $E$. gracilis (Avalos-García et al. 2003).

Similarity of larval composition in the central and interior bay in November is associated with the hydrographic homogeneity of the water column caused by strong prevailing winds. Mixing of the water column is also affected by the high tidal ranges that occur in the central Gulf at that time of year (Instituto of Geofísica 1994). Larvae of Mullidae, Ilypnus gilberti, and Hypsoblennius gentilis, among other shallow demersal species, dominated plankton collections from the central-interior bay, but occurrences of these larvae are rare in the central Gulf (Moser et al. 1974, AvalosGarcía et al. 2003). In addition to Mullidae larvae, the coastal pelagic Etrumeus teres was a dominant species in the bay mouth in November, coinciding with its spawning period in the central Gulf (Moser et al. 1974, GreenRuíz and Acal-Sánchez 1987, Avalos-García et al. 2003). The presence of larvae of mesopelagic species such as Benthosema sp. and Vinciguerria lucetia and deep demersal species such as Merluccius productus in the central and interior bay during November is a clear indicator of the influence of the Gulf waters on the bay at that time. This was possibly the result of intensive mixing in the water column.

\section{ACKNOWLEDGMENTS}

We express our thanks to Instituto Politécnico Nacional (IPN) and CONACyT for supporting this study through project CGEPI 20010817 and CONACy T 34071-T. M.P.I. thanks CONACy'T and CGEPI-IPN for the scholarships, and L.S.-V. thanks SNICONACyT and COFAA-IPN for their financial help. Thanks to B. Shirasago and M. Obeso-Nieblas for the collection of the zooplankton samples and to Ellis Glazier for editing this English-language text. In addition, we thank the anonymous referees for suggesting changes that improved this paper.

\section{Literature Cited}

Abitia, A., J. Rodríguez, and F. Galván. 1990. Observaciones tróficas de tres especies de peces de importancia comercial de Bahía Concepción BCS, México. Invest. Mar. Cent. Interdiscip. Cienc. Mar. 5 (1): 55-61.

Alvarez-Borrego, S., and J. R. Lara-Lara. 1991. The physical environment and primary productivity of the Gulf of California. Pages 555-567 in B. R. T. Simoneit and J. P. Dauplin, eds. The Gulf and Pen- 
insular Province of the Californias. Am. Assoc. Pet. Geol. Mem. 4.

Avalos-García, C., L. Sánchez-Velasco, and B. Shirasago. 2003. Larval fish assemblages in the Gulf of California and their relation to hydrographic variability (autumn 1997summer 1998). Bull. Mar. Sci. 72 (1): in press.

Badan-Dangon, A., J. Koblinsky, and T. Baumgartner. 1985. Spring and summer in the Gulf of California: Observations of surface thermal patterns. Oceanol. Acta $8: 13-22$.

Bray, J. R., and J. T. Curtis. 1957. An ordination of the upland forest communities of southern Wisconsin. Ecol. Monogr. 27:235-249.

Cisneros-Mata, M. A., M. O. NevárezMartínez, M. A. Martínez-Zavala, J. P. Santos-Molina, A. Godínez-Cota, and G. Montemayor-López. 1997. Sinopsis de la pesquería de pelágicos menores del Golfo de California de 1991/92 a 1995/96. Inst. Nac. Pesca, Centro de Regional Investigación Pesquera, Guaymas, México.

Cota-Meza, S., and M. S. Muñeton-Gómez. 1995. Presence of early stages of Opistbonema libertate in Bahía Concepción, B.C.S., México: 1990-1991. Sci. Mar. 59 (3-4): 493-497.

Field, J. G., K. R. Clarke, and M. Warwick. 1982. A practical strategy for analysing multispecies distribution patterns. Mar. Ecol. Prog. Ser. 8: 37-52.

Fisher, W., F. Krupp, W. Schneider, C. Sommer, K. E. Carpenter, and V. H. Niem. 1995. Guía FAO para la identificación de especies para los fines de pesca. FAO, Rome.

Green-Ruíz, Y. A., and D. Acal-Sánchez. 1987. Distribución y abundancia de larvas de peces y estimación de la biomasa desovante de Etrumeus teres en el Golfo de California durante abril de 1985. Cienc. Mar. 13 (3): 69-76.

Green-Ruíz, Y. A., and A. Hinojosa-Corona. 1997. Study of the spawning area of the northern anchovy in the Gulf of California from 1990 to 1994 , using satellite images of sea surface temperatures. J. Plankton Res. 9 (8): 957-968.
Instituto de Geofísica. 1994. Calendario gráfico de mareas 1994. Universidad Nacional Autónoma de México, México, D.F., México.

Jiménez-Rosenberg, P. 1994. Desarrollo larvario de Eucinostomus currani (Pises: Gerreidae). Profesional thesis, Universidad Autónoma de Baja California Sur, La Paz, México.

- 1998. Descripción del desarrollo larvario de Eucinostomus gracilis y larvario y juvenil de Eucinostomus dowii y Diapterus peruvianus. M.S. thesis, Centro Interdisciplinario de Ciencias Marinas (CICIMAR), Instituto Politécnico Nacional, México.

Kramer, D., M. J. Kalin, E. G. Stevens, J. R. Thrailkill, and J. R. Zweifel. 1972. Collecting and processing data on fish eggs and larvae in the California Current region. NOAA Tech. Rep. NMFS Circ. 370.

Lavín, M. F., E. Beier, and A. Badan. 1997. Estructura hidrográfica y circulación del Golfo de California: Escalas estacional e interanual. Pages 141-171 in M. L. Lavín, ed. Contribuciones a la oceanografía física en México. Monografía No. 3, Unión Geofísica Mexicana.

Moser, G. H., ed. 1996. The early stages of fishes in the California Current region. Calif. Coop. Oceanic Fish. Invest. Atlas No. 33. NOAA-NMFS-SFSC, Allen Press, Lawrence, Kansas.

Moser, H. G., E. H. Ahlstrom, D. Kramer, and E. G. Stevens. 1974. Distribution and abundance of fish eggs and larvae in the Gulf of California. Calif. Coop. Oceanic Fish. Invest. Rep. 17:112-128.

Muñetón-Gómez, M. S., S. Cota-Meza, and G. R. Vera. 1994. Primeros registros de la presencia de huevos y larvas de Sardinops caeruleus en Bahía Concepción, BCS, México. Invest. Mar. Cent. Interdiscip. Cienc. Mar. 9 (2): 119-123.

Obeso-Nieblas, M., M. Alatorre-Mendieta, and A. Jiménez. 1996. Modelación de la marea en Bahía Concepción BCS, México. Oceanides 11 (1): 1-8.

Roden, G. J., and G. W. Groves. 1959. Recent oceanographic investigations in the Gulf of California. J. Mar. Res. 18 (1): 1035. 
Rodríguez, R., A. Abitía, F. Galván, and J. de la Cruz. 1992. Lista sistemática de los peces marinos de Bahía Concepción, B.C.S., México. Cienc. Mar. 5 (2): 23-29.

Sánchez-Velasco, L., B. Shirasago, and C. Flores-Coto. 1996. Fish larvae abundance and distribution in the coastal zone off Terminos Lagoon, Campeche (southern Gulf of México). Estuarine Coastal Shelf Sci. 48:707-721.

Sánchez-Velasco, L., B. Shirasago, M. A. Cisneros-Mata, and C. Avalos-García. 2000. Spatial distribution of small pelagic fish larvae in the Gulf of California and its relation to the El Niño 1997-1998. J. Plankton Res. 22 (8): 1611-1618.
Sánchez-Velasco, L., J. E. Valdez-Olguín, B. Shirasago, and M. A. Cisneros-Mata. 2002. Changes in the spawning environment of Sardinops caeruleus in the Gulf of California during El Niño 1997-1998. Estuarine Coastal Shelf Sci. 54:207-217.

Smith, P. E., and S. L. Richardson. 1979. Técnicas modelo para prospección de huevos y larvas de peces pelágicos. FAO Doc. Tec. Pesca 175.

Sokal, R. R., and F. J. Rohlf. 1979. Biometría: Principios y métodos estadísticos en la investigación biológica. H. Blume, Madrid.

Sokal, R. R., and P. H. Sneath. 1963. Principles of numerical taxonomy. W. H. Freeman and Co., San Francisco. 